\title{
MORPHOLOGICAL VARIATIONS OF THE LUNG: A CADAVERIC STUDY IN MUMBAI POPULATION
}

\author{
Deepak Khedekar *1, Shanta Hattangdi ${ }^{2}$. \\ ${ }^{* 1}$ Assistant Professor, Department of Anatomy, LTMMC \& GH, Sion, Mumbai.MH,India \\ ${ }^{2}$ Professor \& Head, Department of Anatomy, LTMMC \& GH, Sion, Mumbai. MH,India \\ ABSTRACT
}

Introduction: The lungs are vital organs of respiration and are situated in the thoracic cavity on either side of the mediastinum. The lungs are divided by fissures into lobes which facilitate movements of lobes in relation to one another during respiration. The arrangement of lung tissue into lobes helps in uniform expansion of the whole lung in inspiration. As a medical specialist detailed knowledge of anatomical variations in lung is important.

Materials and Methods: We studied the variations of fissures, lobes and hilar structures in 25 right and 25 left isolated lungs from the anatomy dissection hall at LTMMC \&GH, Sion, Mumbai, India.

Results: Right lung variations - 8\% were without any fissures. Horizontal fissure was incomplete in $20 \% .1(4 \%)$ showed incomplete oblique fissure and $4 \%$ had accessory fissures. $12 \%$ had 3 arteries, $4 \%$ had only one artery and remaining ( $84 \%)$ had 2 arteries in the hilum. 1(4\%) had one vein in the hilum,2 (8\%) had 3 veins in the hilum remaining $22(88 \%)$ had two veins in the hilum. Only 1 right lung shows one bronchus in the hilum, remaining showed 2 bronchi in hilum.

Left lung variations:1(4\%) showed incomplete oblique fissure and $1(4 \%)$ showed 2 fissures and 3 lobes which is quiet interesting finding. $8 \%$ showed 2 arteries and remaining had only one artery in the hilum. $1(4 \%)$ had one vein in the hilum and 1 ( $4 \%$ ) had 3 veins in the hilum and remaining 92\% having 2 veins in hilum. 6 (24 \%) of had 2 bronchi and 1 (4\%) had only one bronchus in the hilum rest are having 1 bronchus in the hilum.

Conclusion: The knowledge of variations in the lobar and hilar anatomy of the lung presented in this study is clinically important while interpreting the radiological images and performing surgical procedures.

KEY WORDS: Lung, hilum, Pulmonary, lobe, fissure, accessory fissure.

Address for Correspondence: Dr.Deepak N.Khedekar, Department of Anatomy, Lokamanya Tilak Municipal Medical College \& GH, Sion, Mumbai, India.400022 Tel: +91-02224063214

Mobile-9224449950 E-Mail: drdeepak2025@yahoo.co.in

\begin{tabular}{|c|c|c|}
\hline \multicolumn{3}{|c|}{ Access this Article online } \\
\hline \multirow{2}{*}{$\begin{array}{l}\text { Quick Response code } \\
\text { DOI: } 10.16965 / \text { ijar.2017.320 }\end{array}$} & \multicolumn{2}{|c|}{$\begin{array}{l}\text { Web site: International Journal of Anatomy and Research } \\
\qquad \text { ISSN 2321-4287 } \\
\text { www.ijmhr.org/ijar.htm }\end{array}$} \\
\hline & $\begin{array}{l}\text { Received: } 23 \text { June } 2017 \\
\text { Peer Review: } 24 \text { June } 2017 \\
\text { Revised: None }\end{array}$ & $\begin{array}{l}\text { Accepted: } 03 \text { Aug } 2017 \\
\text { Published (O): } 31 \text { Aug } 2017 \\
\text { Published (P): } 31 \text { Aug } 2017\end{array}$ \\
\hline
\end{tabular}

\section{INTRODUCTION}

The lungs are vital organs of respiration and are situated in the thoracic cavity on either side of the mediastinum. The lungs are divided by fissures into lobes which facilitate movements of lobes in relation to one another during respiration. The arrangement of lung tissue into lobes helps in uniform expansion of the whole lung in inspiration [1, 2]. The right lung is divided into three lobes namely upper, middle and lower by oblique and horizontal fissures. The left lung is divided into two lobes namely upper and lower by oblique fissure. On medial side, behind the cardiac impression in mediastinal surface, each lung shows a triangular depression named the hilum, where the structures which form the root 
of the lung enter and leave the organ. Right lung admit two pulmonary veins and two pulmonary artery through the hilum while left lung admit two pulmonary veins and one pulmonary artery through the hilum. The bronchi differ in their mode of subdivision between the left and right lungs [1].

The right bronchus gives off a branch (eparterial bronchus) to the superior lobe about $2.5 \mathrm{~cm}$ from the bifurcation of the trachea. Other division come off below the artery (hyparterial bronchus). The left bronchus passes below the level of pulmonary artery before it divides and so all its branches are hyparterial. Awareness of the normal anatomy is very essential foundation of the surgical knowledge. Though the fissures and the lobar pattern of the lungs are studied in a few populations, the hilar anatomy of the lungs has been overlooked [3]. Anatomical variation may lead to misinterpretation of a radiological scan [4]. Certain radiological findings can be misleading the diagnosis as in the cases of extra lobes, as it may misinterpret as lung lesions. In the presence of extra lobes, the CT scan shows a significant increase in the size of mediastinum around the trachea [5]. The accessory fissure might alter usual pattern of lung collapse in patients with endobronchial lesion which can be again misleading. Normally pneumonia will be restricted to the lobes affected by it, but in patients with incomplete fissures, it may spread to adjacent lobes [6, 7]. In the current study, we have discussed on the morphological variations of the lungs in the Mumbai population.

\section{MATERIALS AND METHODS}

50 adult formalin fixed cadaveric lungs preserved in the dissection hall at LTMMC \& GH were observed for the study. The lungs belonged to the adult age group between 20 to 70 years. No gender difference of the lungs was made in this study. Only those lungs which were covered all over by pleura except at the hilum were used in the study. If any part of the lung was cut off during its removal, such lung was excluded from the study. Out of 50 lungs, 25 were right lungs, and 25 were left lungs. Following parameters were noted in the current study:

1. Number of fissures

Int J Anat Res 2017, 5(3.2):4313-16. ISSN 2321-4287
2. Number of lobes and

3. Variations in the hilar structures.

\section{RESULTS}

Table 1: Showing the various features of lungs found in either side.

\begin{tabular}{|c|c|c|c|c|c|}
\hline \multicolumn{3}{|c|}{ Right lung ( $n=25$ ) } & \multicolumn{3}{|l|}{ Left Lung ( $n=25$ ) } \\
\hline Feature & Total & $\%$ & Feature & Total & $\%$ \\
\hline No fissure & 2 & 8 & Incomplete oblique fissure & 1 & 4 \\
\hline Incomplete horizontal & 5 & 20 & Presence of horizontal fissure & 2 & 8 \\
\hline Incomplete oblique fissure & 1 & 4 & Accessory fissure & 4 & 16 \\
\hline Absent oblique fissure & 1 & 4 & Three lobes & 1 & 4 \\
\hline One artery in the hilum & 1 & 4 & Two arteries in the hilum & 2 & 8 \\
\hline Three arteries in hilum & 3 & 12 & Three veins in the hilum & 1 & 4 \\
\hline Three veins in hilum & 2 & 8 & Two bronchi in the hilum & 6 & 24 \\
\hline Accessory fissure & 1 & 4 & Four bronchi in the hilum & 1 & 4 \\
\hline One bronchus & 1 & 4 & Lingula absent & 1 & 4 \\
\hline
\end{tabular}

Fig. 1: Right lung with 2 principal bronchi.

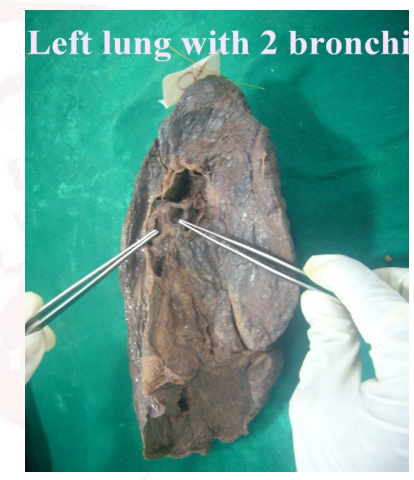

Fig. 2: Left lung with 3 lobes.

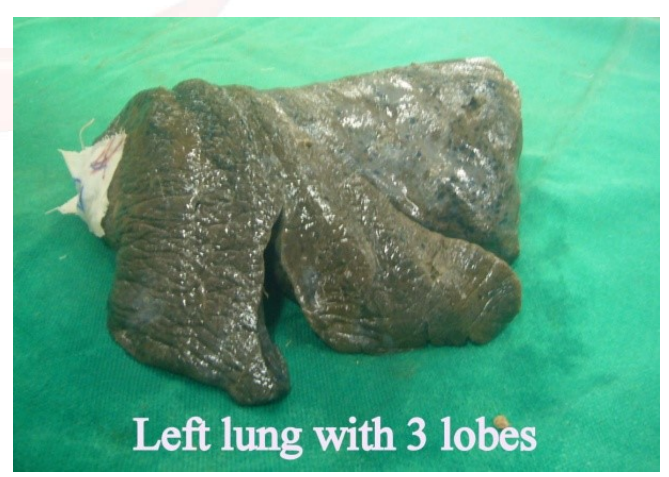

Fig. 3: Left lung with one pulmonary vein.

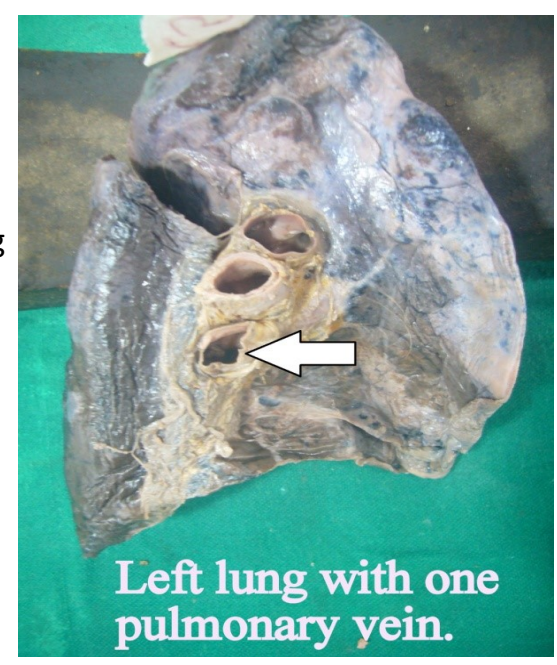


Fig. 4: Right lung with no fissure.

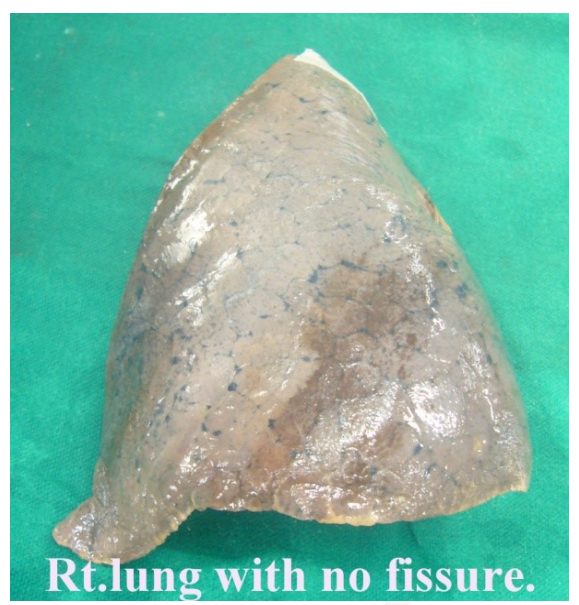

Fig. 5: Right lung with incomplete horizontal fissure.

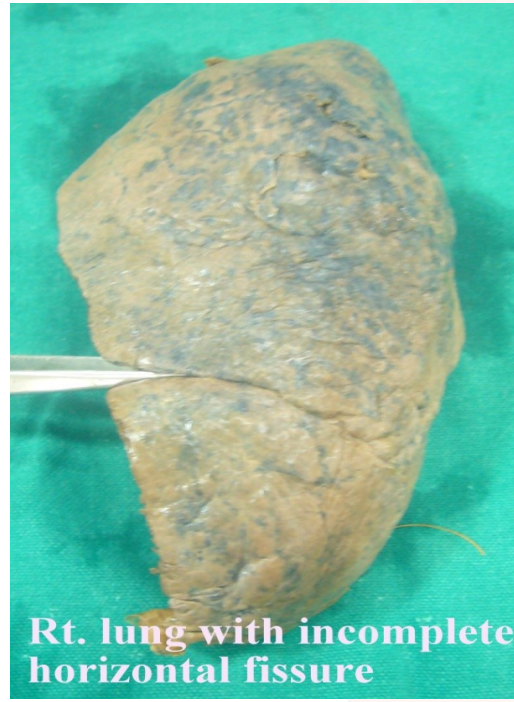

Fig. 6: Right lung with accessory fissures on diaphragmatic surface.

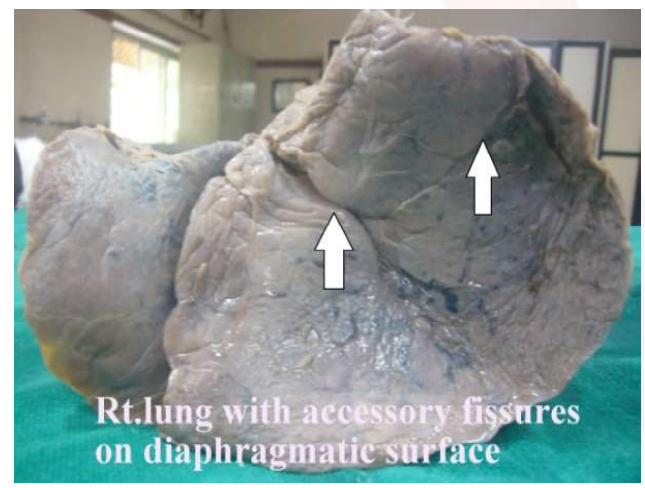

\section{DISCUSSION}

Many researchers have reported the anomalous anatomy of the lungs in human cadavers [3-14]. During development of the lungs numerous bronchopulmonary buds are formed and later they fuse completely except at the sites of fissure formation. This results in the formation of lobes and fissures. Incomplete fissure formation could be due to partial obliteration of these fissures [8]. Accessory fissure could be the result of non- fusion of spaces between the bronchopulmonary buds which normally are obliterated. Any factor affecting the fusion in the developmental stage leads to variations in the formation of lobes and fissures of the lung [4]. In our literature study, we could find a few reports on variations of the fissures of the lungs [15-18].

Knowledge of development of minor lung segments and pulmonary veins is also useful clinically [19].When compared to the previous studies, we found a higher incidence of incomplete horizontal fissures in right lung [9-11]. We noticed $1(4 \%)$ case of absence of oblique fissure in right lung which was reported by earlier researchers as $2 \%$ for right [12]. $4 \%$ of left lungs in the current study showed incomplete oblique fissure, whereas the previous studies report the incidence of this variation as $12 \%$ \& 47\% [11] .Accessory lobes and fissures can be misinterpreted on X-rays and CT scans. In our study, we noticed accessory fissure $4 \%$ in right side and $16 \%$ in left side. One left lung showed complete accessory fissure, dividing it into 3 lobes instead of 2 lobes. Some of the previous studies also report the presence of accessory lobes of lungs [20-22].

\section{CONCLUSION}

Knowledge of the fissures and lobes of the lungs are important to plan various surgical procedures to avoid post-operative complications. It can also help to explain various radiological appearances of lobar anatomy of the lungs and the position of the interlobar fluid. The results of the present study and their comparison with the previous studies shows that a variety of variations can occur at the hilar structures as well as the shape, fissures and lobes of the lungs in humans. Variations in the number and pattern of hilar structures in both human lungs have not been studied in detail by earlier researchers, thus this study add a database for the same. Prior anatomical knowledge and suspicion for probable variations may be crucial for clinicians, surgeons and radiologists.

\section{ACKNOWLEDGEMENTS}

All authors are thankful to Department of Anatomy, LTMMC \&GH, Mumbai. Authors of this study also acknowledged to authors, editors, and 
publishers of all those articles, journals and books from where literature for this article has been reviewed and discussed.

\section{Conflicts of Interests: None}

\section{REFERENCES}

[1]. Shah P, Johnson D, Standring S. Thorax. In: Standring S, editor. Gray's Anatomy: The Anatomical Basis of Clinical Practice. 39thed. Edinburgh: Churchill Livingstone; 2005, 1068-9.

[2]. Rosse C, Gaddum-Rosse P. Hollinshead's textbook of anatomy. Philadelphia: Lipincott Williams \& Wilkins; 1997,441-61.

[3]. Brahmbhatt RJ, Chauhan KB, Bansal M, Brahmbhatt JN. Cadaveric study of azygous lobe of lung. Int J Basic Appl Med Sci 2013; 3: 30-3.

[4]. Meenakshi S, Manjunath KY, Balasubramanyam V. Morphological variations of the lung fissures and lobes. Indian J Chest Dis Allied Sci 2004; 46,179-82.

[5]. Speckman JM, Gamsu G, Webb WR. Alterations in CT mediastinal anatomy produced by an azygos lobe. AJR Am J Roentgenol 1981;137,47-50.

[6]. Aldur MM, Denk CC, Celik HH, Tasçioglu AB. An accessory fissure in the lower lobe of the right lung. Morphologie 1997; 81,5-7.

[7]. Tarver RD. How common are incomplete pulmonary fissures, and what is their clinical significance? AJR Am J Roentgenol 1995;164,761.

[8]. Larsen WJ. Human embryology. New York: Churchill Livingstone;1993,111-30.

[9]. Polaczek M, Religioni J, Orºwski T. Anatomic variations of pulmonary vessels relevant with regard to lung tissue resections: literature review and personal experiences. Kardiochir Torakochirurgia Pol 2013; 10,232-238.

[10]. Prakash, Bhardwaj AK, Shashirekha M, Suma HY, Krishna GG, Singh G. Lung morphology: a cadaver study in Indian population.Ital J Anat Embryol 2010;115,235-240.

[11]. Nene AR, Gajendra KS, Sarma MV. Lung lobes and fissures: a morphological study. Anatomy 2011;5.30-38.
[12]. Ghosh E, Basu R, Dhur A, Roy A, Roy H, Biswas A. Variations of fissures and lobes in human lungs: $A$ multicentric cadaveric study from West Bengal, India. Int J Anat Radiol Surg 2013;2,5-8.

[13]. Sharma G, Vijayvergiya T. Anatomical variations in lobar pattern of the lungs: anatomical study and clinical significance. J.Pharm Biomed Sci 2013; 26,301-303.

[14]. Mayuri J, Pradeep P, Vasudha N, Aparna T, Smita M. Anomalous Lobar pattern of right lung: a case report. J Res Med Den Sci 2013; 1, 80-81.

[15]. Berkmen T, Berkmen YM, Austin JH. Accessory fissures of the upper lobe of the left lung: CT and plain film appearance. AJR Am J Roentgenol 94; 162, 12871293.

[16]. Frija J, Schmit P, Katz M, Vadrot D, Laval-Jeantet $M$. Computed tomography of the pulmonary fissures: normal anatomy. J Comput Assist Tomogr. 1982;6:1069-1074.

[17]. Medlar EM. Variations in interlobar fissures. Am J Roentgenol Radium Ther 1947;57:723-725.

[18]. Otsuji H, Uchida H, Maeda M, Iwasaki S, Yoshiya K, Hatakeyama M, Ohishi H, lioka S, Kitamura S, Narita N. Incomplete interlobar fissures: bronchovascular analysis with CT. Radiology 1993;187:541-546.

[19].Abe S, Yamamoto M, Noguchi T, Yoshimoto T, Kinoshita H, Matsunaga S, Murakami G, RodríguezVázquez JF. Fetal Development of the minor lung segment. Anat Cell Biol 2014;47:12-17.

[20]. Speckman JM, Gamsu G, Webb WR. Alterations in CT mediastinal anatomy produced by an azygos lobe. AJR Am J Roentgenol 1981;137:47-50.

[21]. Aldur MM, Denk CC, Celik HH, Tasçioglu AB. An accessory fissure in the lower lobe of the right lung. Morphologie 1997;81:5-7.

[22]. Esomonu UG, Taura MG, Modibbo MH, Egwu AO. Variation in the lobar pattern of the right and left lungs: A case report. Australas Med J 2013;6:511514.

How to cite this article:

Deepak Khedekar, Shanta Hattangdi. MORPHOLOGICAL VARIATIONS OF THE LUNG: A CADAVERIC STUDY IN MUMBAI POPULATION. Int J Anat Res 2017;5(3.2):4313-4316. DOI: 10.16965/ijar.2017.320 